\title{
Polyphenol Oxidase (PPO) in Early Stage of Browning of Phalaenopsis Leaf Explants
}

\author{
Zhiwei $\mathrm{Ru}^{1}$, Yanyan Lai ${ }^{1}$, Chuangjun $\mathrm{Xu}^{2} \&$ Ling $\mathrm{Li}^{1}$ \\ ${ }^{1}$ College of Life Science, Guangdong Key Laboratory of Biotechnology for Plant Development, South China \\ Normal University, Guangzhou, China \\ ${ }^{2}$ Fujian Provincial Key Lab of Subtropic Plant Physiology and Biochemistry, Fujian Institute of Subtropic Botany, \\ Xiamen, China \\ Correspondence: Ling Li, College of Life Science, Guangdong Key Laboratory of Biotechnology for Plant \\ Development, South China Normal University, Guangzhou 510631, China. Tel: 86-139-0307-2650. E-mail: \\ liling502@126.com
}

Received: June 13, 2013 Accepted: July 17, 2013 Online Published: August 15, 2013

doi:10.5539/jas.v5n9p57 URL: http://dx.doi.org/10.5539/jas.v5n9p57

\begin{abstract}
Explant browning is one of the most common problems during the early stage of tissue culture. The aim of this study was to explore the roles of polyphenol oxidase (PPO, EC 1.10.3.2) in the browning process of leaf explants of Phalaenopsis (Doritaenopsis Queen Bee "Red Sky") under a routine culture condition. Along with the observation of the time course of browning and PPO distribution, PPO gene expression in leaf explants were investigated. In addition, the expression and activity of PPO were also examined. This work provides some insights into further understanding the relationship between PPO activation and explant browning.
\end{abstract}

Keywords: phalaenopsis explants, enzymatic browning, polyphenol oxidase

\section{Introduction}

Explant browning can occur in laboratory and in nature (Martini et al., 2013). It is one of the major problems in the tissue culture process and generally considered to be associated with the enzymatic oxidation of phenolic compounds. Polyphenol oxidase (PPO), peroxidase (POD), and L-phenylalanine ammonialyase (PAL) are three major proteases involved in plant tissue browning (Mikal, 2000; Xu \& Li, 2006). PPO is an enzyme widely distributed in plants and catalyzes two types of reactions: (a) hydroxylation of phenols (such as tyrosine) to an o-diphenol (cresolase activity) (EC1.14.18.1) and (b) oxidation of diphenols to o-quinones (catecholase activity) (EC 1.10.3.1). PPO is a copper-containing enzyme which uses oxygen molecule as a co-substrate (Mayer, 2006).

Enzymatic browning in plants is mainly related to the oxidation of phenolic compounds to unstable o-quinones which are highly electrophilic molecules and their polymerization can lead to the appearance of brown, red or black pigmentation (Mayer \& Harel, 1979; Holderbaum et al., 2010). The degree of browning depends on the nature and amount of phenolic compounds, the presence of oxygen, reducing substances, metal ions, $\mathrm{pH}$, temperature, and the activity of PPO as well (Yoruk \& Marshall, 2003).

At present, plant tissue culture is mainly used for the rapid propagation of Phalaenopsis. However, explant browning can impair the success of the rapid propagation. A recent in vitro study utilizing the variety 'R4' of Phalaenopsis demonstrated that the browning of the explants could be affected by $\mathrm{pH}$ and temperature (Zhao et al., 2006). The tissue browning of Phalaenopsis is also closely related to the phenol concentration of explant. After Phalaenopsis explant browning, the vascular bundle is filled with tannin and the upper epiderm becomes shriveled (Xu et al., 2005).

Enzyme activity of protease PPO and POD is closely related to explant browning of Phalaenopsis. It has been reported that the POD enzyme activity gradually increase at the beginning of culture and then begin to decrease while the PPO activity rises during the first 6 days then gradually declines (Xu \& $\mathrm{Li}, 2006)$. In the browning explants of Phalaenopsis, the content of total phenol compounds and the activity of PAL can also increase in culture conditions (Xu et al., 2005).

Previously, we examined the total proteins of browning Phalaenopsis leaf explant using proteomic method. LCQMS/MS assay identified the presence of peroxiredoxin, mitochondrial F-1-ATPase subunit 2, and regulatory 
protein-like protein (Chen et al., 2012). In this study, we further investigated the expression pattern of $P P O$ during the browning of Phalaenopsis leaf explants in in vitro culture. The tissue-specific distribution of PPO protein in the leaf explant of Phalaenopsis were examined and the pattern of PPO protein synthesis and PPO enzyme activity were assayed in order to provide some insights into the relationship between the PPO and Phalaenopsis leaf explant browning.

\section{Materials and Methods}

\subsection{Preparation of Plant Materials}

Phalaenopsis (Doritaenopsis Queen Bee "Red Sky") seedlings (from Botanical Garden of South China Normal University) were grown on MS medium containing active carbon $(1 \mathrm{~g} / \mathrm{L})$. Light intensity was maintained at 35 $\mu \mathrm{mol} \cdot \mathrm{m}^{-2} \cdot \mathrm{s}^{-1}$ with $16 \mathrm{~h}$-day/8h-night cycle and temperature controlled at $24 \pm 2{ }^{\circ} \mathrm{C}$. Leaves of Phalaenopsis seedlings were cut into $0.5 \mathrm{~cm} \times 0.5 \mathrm{~cm}$ segments and immediately transferred to fresh MS medium containing 6-benzylaminopurine $(3 \mathrm{mg} / \mathrm{L})$. All cultures were maintained under cool white fluorescent light of approximately $35 \mu \mathrm{mol} \cdot \mathrm{m}^{-2} \cdot \mathrm{s}^{-1}$ photon flux density and $16 \mathrm{~h}$-day/8h-night cycle at $24 \pm 2{ }^{\circ} \mathrm{C}$. Leaf explants were collected at 0,6 , $12,24,48$ and $72 \mathrm{~h}$, respectively and frozen immediately in liquid nitrogen and stored at $-80{ }^{\circ} \mathrm{C}$.

\subsection{Evaluation of Browning}

The browning of the cut edges of the lettuce segments was evaluated visually and the number of explants showing brown pigment was counted.

\subsection{Analysis of PPO Gene Expression}

Semi-quantitative RT-PCR was used to analyze PPO gene transcription. Total RNA extracts of leaf samples obtained at $0,6,12,24$ and $72 \mathrm{~h}$ were used to synthesize the first strand of cDNA by TaKaRa PrimeScript RT reagent Kit. cDNA was used as a template for amplifying a partial sequence of the $P P O$ gene. The full length of cDNA of $P h P P O$ is $1851 \mathrm{bp}$ with an open read frame of $1647 \mathrm{bp}$ (Xu et al., 2009). The PPO primers were designed as PPO-F (5'-AATATGTGGCGAAGTACGCC-3') and PPO-R (5'-GATCCCGTTCGCCTCCAATA-3'). $\beta$-Actin was used as the internal control to verify the RT-PCR reaction. The primers of the internal control gene were designed as ACT-F (5'-ATTGTAAGGGACGTGAAGGAGAAGC-3') and ACT-R (5'-AAGTAGTCTCATGGATTCCCGCTGC-3'), respectively. The PCR reaction mixture $(20 \mu \mathrm{L})$ contained $2 \mu \mathrm{L}$ $10 \times$ PCR buffer, $1.6 \mu \mathrm{L}$ dNTPs $(2.5 \mathrm{mM}), 0.4 \mu \mathrm{L}(10 \mathrm{mM})$ of each primers, $1 \mu \mathrm{L}$ DNA template and $0.1 \mu \mathrm{L}$ Taq (5 U, Fermentas), $14.5 \mu \mathrm{L} \mathrm{H}_{2} \mathrm{O}$. The cycling conditions were $94{ }^{\circ} \mathrm{C}, 5 \mathrm{~min}$ for initial denaturation and a total of 27 cycles of $94{ }^{\circ} \mathrm{C}$ for $30 \mathrm{~s}, 55^{\circ} \mathrm{C}$ for $30 \mathrm{~s}$ and $72{ }^{\circ} \mathrm{C}$ for $30 \mathrm{~s}$, followed by a final extension at $72{ }^{\circ} \mathrm{C}$ for $10 \mathrm{~min}$.

\subsection{PhPPO Antibody Preparation}

The PPO gene was cloned from Phalaenopsis and PhPPO protein was generated from BL21 (DE3) cells (Xu et al., 2009). Purified PhPPO protein was submitted to Invitrogen and used to raise polyclonal antibodies against PPO from the rabbit. The crude antiserum was purified by affinity purification and used as anti-PhPPO polyclonal antibodies in immunostaining and western blot assays.

\subsection{In Situ Immunostaining of PPO}

Leaf samples were fixed at $4{ }^{\circ} \mathrm{C}$ in $2 \%(\mathrm{w} / \mathrm{v}) \mathrm{EDC}, 3 \%(\mathrm{w} / \mathrm{v})$ paraformaldehyde, $05 \%(\mathrm{v} / \mathrm{v})$ glutaraldehyde and $4 \%$ $(\mathrm{w} / \mathrm{v})$ sugar in $10 \mathrm{mmol} / \mathrm{L}$ PBS buffer ( $\mathrm{pH}$ 7.2). The samples were dehydrated with 30\% (w/v) sugar. Leaf cross-sections in $20 \mu \mathrm{m}$ thickness were cut with a microtome (Sorvall MT-6000 ultramicrotome) and dried on object glass slides. Immunoenzyme detection of extensins in the sections was performed using the streptavidin method. The sections were blocked with 5\% BSA in PBS, then incubated with anti-PhPPO polyclonal antibodies (1:200 in 5\% BSA/10 mM PBS, pH 7.2) at $4{ }^{\circ} \mathrm{C}$ overnight. Slides were rinsed three times with PBS and incubated with a HRP-labeled goat anti-rabbit IgG antibody (1:200) (Bio Rad) at $37^{\circ} \mathrm{C}$ for $20 \mathrm{~min}$. Following triple washing with PBS, the sections were treated with DAB at room temperature for $10 \mathrm{~min}$ and then washed with distilled water. The localization of PPO was examined under a microscope (Olympus IX-70, Japan). Sections treated with $\mathrm{PBS} / \mathrm{BSA}$ solution without primary antibody were used as negative controls.

\subsection{Analysis of PPO Synthesis by Western Blotting}

Frozen leaf explants $(0.5 \mathrm{~g})$ were ground in liquid nitrogen to a fine powder and then homogenized in $1 \mathrm{~mL}$ pre-cooled lysis buffer (Keygen Biotech, Guangzhou, China) containing $1 \mu \mathrm{L}$ protease inhibitor, $10 \mu \mathrm{L}$ DTT (1M) and $10 \mu \mathrm{L}$ PMSF $(100 \mathrm{mM})$. The homogenate was centrifuged at $14,000 \mathrm{~g}$ for $10 \mathrm{~min}$ at $4{ }^{\circ} \mathrm{C}$. The supernatant, referred to as the crude enzyme extract, was used in western blot analysis. For western blots and protein analyses, soluble proteins $(50 \mu \mathrm{g}$ total protein) were separated on SDS-PAGE (12\% acrylamide) gels and either visualized by Coomassie Blue staining or transferred to NC membranes (Millipore corporation, Billerica, USA) to react 
with anti-PhPPO polyclonal antibodies (1:2000 in 5\% dried nonfat milk). Immunocom-plexes were detected with HRP-labeled goat anti-rabbit IgG antibody. The protein content was determined by the Bradford method using bovine serum albumin (BSA) as the standard.

\subsection{PPO Activity Assay}

Frozen leaf explants of Phalaenopsis $(200 \mathrm{mg}$ ) were mixed with $2 \mathrm{ml}$ pre-cooled $0.2 \mathrm{M}$ sodium phosphate buffer (pH 8.0) containing $0.1 \%$ TritonX-100. The homogenate was centrifuged at $12,000 \mathrm{~g}$ for $10 \mathrm{~min}$ at $4{ }^{\circ} \mathrm{C}$. The supernatant, referred as the crude enzyme extract, was collected and stored at $-20^{\circ} \mathrm{C}$. For PPO activity assay, 0.2 $\mathrm{ml}$ crude enzyme extract was mixed with $3 \mathrm{ml} 2 \mathrm{M}$ phosphate buffer $(\mathrm{pH} 8.0)$ and $0.2 \mathrm{ml} \%$ catechol. The reaction was carried out at $32{ }^{\circ} \mathrm{C}$. The changes in absorbance at $310 \mathrm{~nm}$ were recorded by a spectrophotometer (UV6000PC, Shanghai Metash Instruments Co.) every $20 \mathrm{~s}$ for $2 \mathrm{~min}$. PPO activity was expressed as units $\mathrm{mg}^{-1}$ protein. One unit of PPO activity was defined as the change in absorbance of $0.001 \mathrm{~min}^{-1} \mathrm{mg}^{-1}$ of enzyme. The protein content was determined as described above.

\subsection{Statistical Analyzes}

Browning percentage and enzymatic activity were expressed as the mean values of three independent experiments. Statistical analysis was carried out using the Student's $t$-test by SPSS statistical package (SPSS 17.0 version). Each time point had two replicates, and experiments were repeated three times.

\section{Results}

\subsection{Browning of Phalaenopsis Leaf Explants Under Routine Culture Condition}

The browning areas in the cut sections of Phalaenopsis leaf explants collected at Day 1,2, 3 and 6 were visually examined, respectively. The browning percentages were calculated using the fresh cut $(0 \mathrm{~h})$ of Phalaenopsis leaf explants as a control. As shown in Figure 1, the leaf explants gradually turned brown under routine culture condition. The browning spots could hardly be observed at Day 1, however, there were $25.0 \pm 3.0 \%$ and $42.0 \pm 2.6 \%$ sections of cut leaf explants that turned brown at Day 2 and 3, respectively.

\subsection{Three Phases of PPO Gene Expression in Phalaenopsis Leaf Explants}

The $P P O$ homolog, designated as $P h P P O$, was cloned from Phalaenopsis leaf explants by RT-PCR and RACE. The time course of PPO gene expression pattern is shown in Figure 2. No PPO gene expression could be observed in the fresh cut (i.e. $0 \mathrm{~h}$ ) but a strong expression was seen at $6 \mathrm{~h}$. There were a noticeable expression of $P P O$ gene at 12 and $24 \mathrm{~h}$ but the expression level was much lower compared to $6 \mathrm{~h}$. Then the $P P O$ expression level raised up again at $72 \mathrm{~h}$ but was still lower than $6 \mathrm{~h}$. Based on these results, it could be suggested that for the first 3 days the $P P O$ gene expression of Phalaenopsis leaf explants in the culture condition could be divided into three phases: the rapid response phase $(6 \mathrm{~h})$, the fatigue phase (12 to $24 \mathrm{~h})$ and second response phase $(72 \mathrm{~h})$.

\subsection{Tissue-Specific Distribution of PPO Protein in Phalaenopsis Leaf Explants}

The distribution of PPO protein in leaf tissues was examined using an in situ immunostaining method (Figure 3). At $6 \mathrm{~h}$, the PPO protein was mainly located in the vascular tissues enriched in the vascular wall (Figure 3B and $3 \mathrm{~F}$ ) and deep in the epidermis compared to the control (Figure 3C and 3D). At $72 \mathrm{~h}$, the location of PPO protein rich vascular tissues was deepened compared to $6 \mathrm{~h}$ (Figure 4), indicating that more PPO proteins were synthesized at $72 \mathrm{~h}$ than at $6 \mathrm{~h}$.

\subsection{PPO Protein Synthesis and Activity}

Early study has shown that $P h P P O$ encodes a protein of 549 amino acids with a molecular mass of $60.43 \mathrm{kD}$ and shares the characteristics of tyrosinase family (Xu et al., 2009). To confirm the synthesis pattern of PPO protein in Phalaenopsis leaf, western blot was performed to evaluate the PPO protein levels. As shown in Figure 5, the PPO protein presented in samples collected at every time point. Compared to the fresh cut leafs $(0 \mathrm{~h})$ there was no significant increase at 6,12 or $24 \mathrm{~h}$. However, there was a significant increase at $72 \mathrm{~h}$, nearly two times higher than $0 \mathrm{~h}$. These results indicated that intrinsic PPO existed in Phalaenopsis leaf explants before being subjected to culture and its level gradually increased during tissue browning and maximized at Day 3 . This was consistent with the results of PPO activity assay. As shown in Figure 6, the PPO activity was relativity stable and maintained at the baseline level $(0 \mathrm{~h})$ at least up to the first $24 \mathrm{~h}$ in culture. The enzyme activity increased significantly at $72 \mathrm{~h}$, which was 0.9 times higher than that of the baseline level. 


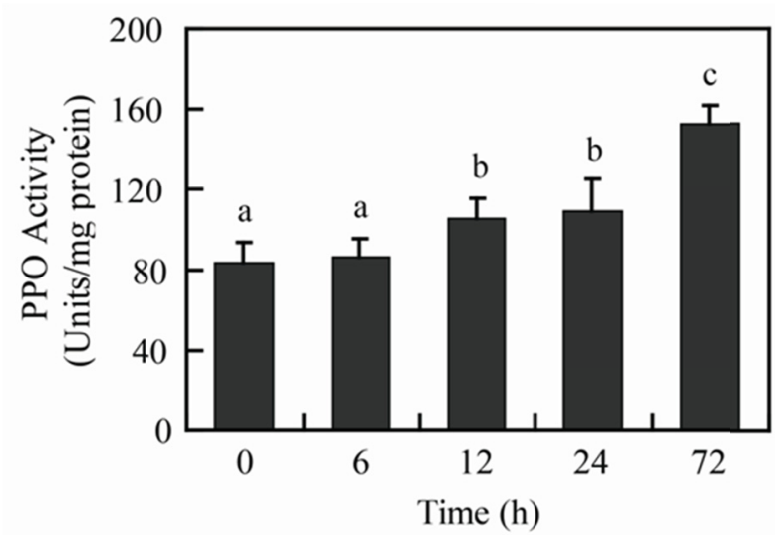

Figure 6. The time course of PPO enzyme activity of Phalaenopsis leaf explants. Different letters indicate statistical difference $(\mathrm{P}<0.05)$

\section{Discussion}

Numerous studies suggest that PPO is responsible for enzymatic browning of plants. Murata et al. (2001) demonstrated that the browning potential was lowered in a transgenic apple callus in which antisense $P P O$ gene was introduced and the expression of PPO was repressed. In the presence of chlorogenic acid the browning potential of transgenic line was half of non-transgenic callus. In this study, the expression level of $P P O$ gene showed significant changes during the browning of Phalaenopsis leaf explants under the routine culture condition. There was no PPO gene expression before culture but it rapidly responded at $6 \mathrm{~h}$ and leaf explant browning could be detected at the same time. Then in the second period between $12 \mathrm{~h}$ and $24 \mathrm{~h}$ and when the browning happened, $P P O$ gene expression decreased but could still be detected. When cultured for $72 \mathrm{~h}, P P O$ gene expression increased again and nearly half of the leaf explants turned brown (see Figures 1 and 2).

7

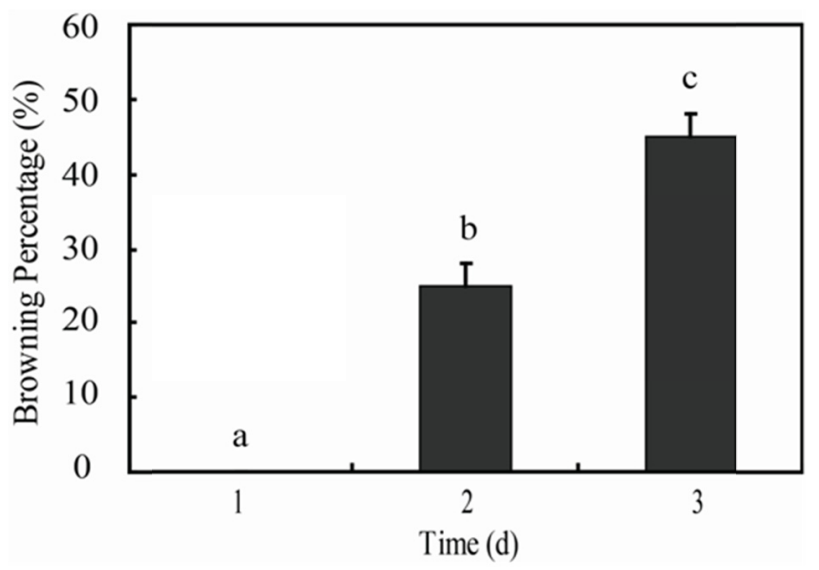

Figure 1. The relationship of browning percentage and culture time. Different letters indicate statistical difference $(\mathrm{P}<0.05)$

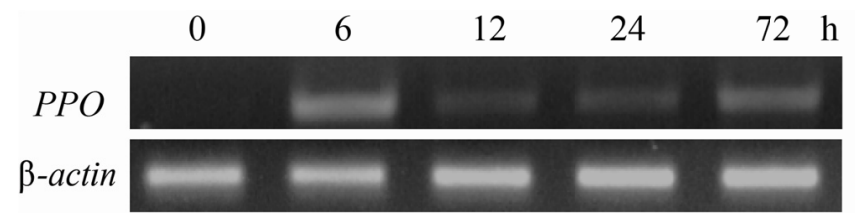

Figure 2. The time course of $P P O$ gene expression of Phalaenopsis leaf explants. Different letters indicate statistical difference $(\mathrm{P}<0.05)$ 
Analyses of PPO protein synthesis and PPO activity from Phalaenopsis leaf explants showed that both the amount and activity were increased at $72 \mathrm{~h}$. The amount of PPO protein at $72 \mathrm{~h}$ was about two times that of the fresh cut while PPO enzymatic activity at $72 \mathrm{~h}$ was 0.9 times higher than that of fresh cut (see Figure 5 and 6 ). It might be suggested that when the Phalaenopsis leaf explants were cultured in vitro, PPO gene expression was induced and then the PPO protein synthesized, which resulted in the increase of PPO level and activity and ultimately enzymatic browning occurred. Our results also showed that the PPO protein level and activity in the fresh cut leaf explants were relatively high (see Figure 5 and 6), which suggests the presence of both constitutive and induced PPOs. The reasons for the frequently observed latency of the enzyme and how it is converted into the active form in in vivo condition are still not clear (Mayer, 2006).

Some previous studies show that the synthesis of PPO and its transport to its site in chloroplasts where plant PPOs are thought to be located are a complex process. Nevertheless, this process has the general features of import of nuclear coded proteins into sub-cellular organelles (Sommer et al., 1994; Underhill \& Critchley, 1995; Murata et al., 1997). In this study, we showed that PPO protein mainly distributed in the vascular tissues and epidermis that may be the initial synthetic locations (see Figure 3). The location of vascular tissue at $72 \mathrm{~h}$ and $6 \mathrm{~h}$ were compared and it was deeper at $72 \mathrm{~h}$ than at $6 \mathrm{~h}$, indicating that there were more PPO protein synthesized at $72 \mathrm{~h}$ (see Figure 4). This was consistent with the results of PPO synthesis analyzed by western blot which was also showed increased PPO level in culture at $72 \mathrm{~h}$ (see Figure 5).

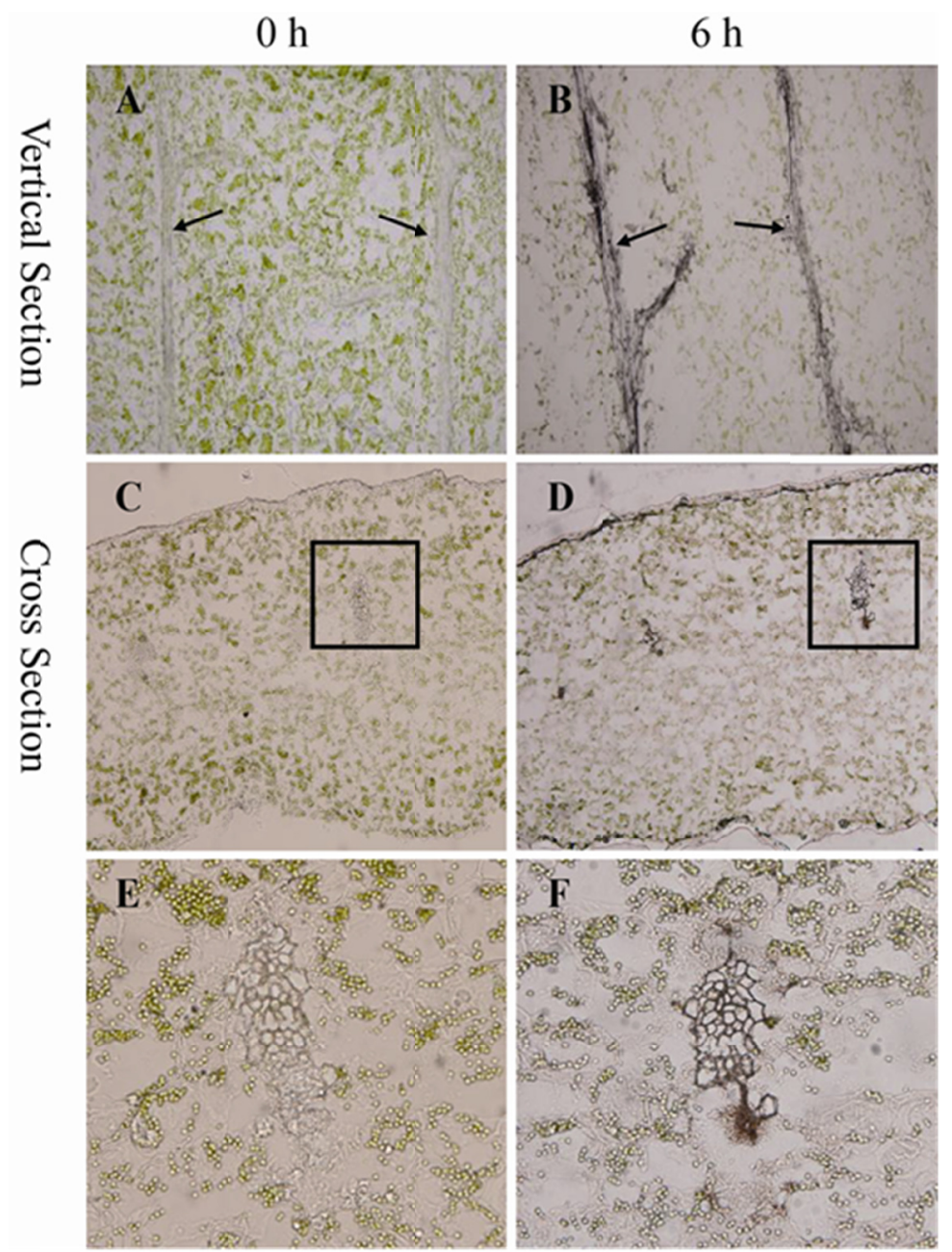

Figure 3. Localization of PPO protein in Phalaenopsis leaf explants. Left panel: control and right panel: $6 \mathrm{~h}$. A and B: vertical section; $C$ and D: cross section. $\mathrm{E}$ and F: the close up images of the vascular tissue. DAB stained PPO protein shows brown color. Arrows indicate the vascular bundle 
$6 \mathrm{~h}$

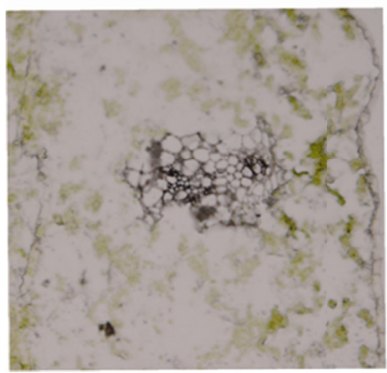

$72 \mathrm{~h}$

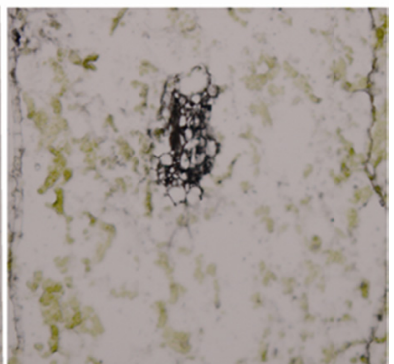

Figure 4. Comparison of PPO protein expression at $6 \mathrm{~h}$ and $72 \mathrm{~h}$. More DAB stained PPO proteins were seen at 72 $\mathrm{h}$

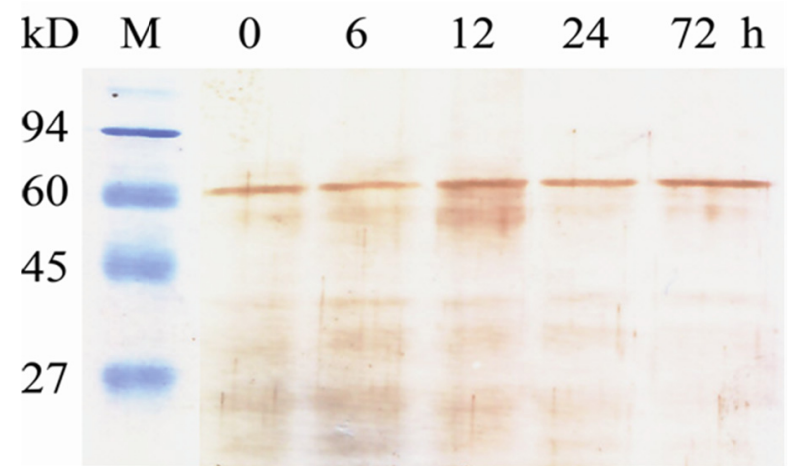

Figure 5. The Western blot assay of PPO protein from Phalaenopsis leaf explants

It is important to explore the mechanisms of tissue browning. Early studies show that phenolic metabolism and PPO can be induced by abiotic stresses such as cutting, wounding or chilling and result in tissue browning (Thipyapong \& Steffens, 1997; Constabel et al., 2000; Mikal, 2000; Stewart et al., 2001). Zhao et al. (2010) suggest that cutting is the cause of browning in Phalaenopsis tissue culture. Cutting wounds can induce an imbalance of reactive oxygen species (ROS) metabolism, peroxidation of membrane lipid, and loss of cell membrane integrity which lead to the over-accumulation of phenolic compounds and ultimately tissue browning can occur.

Enzymatic browning is tightly connected with the browning of Phalaenopsis culture leaf explants. Some studies show that aging and stress can lead to lower ATP production and higher ROS accumulation, which can cause membrane system disorder and trigger the browning process (Franck et al., 2007; Jiang, 2000). Previously, we reported that the PPO and POD isoenzymes from the leaf explants of Phalaenopsis showed no PPO or POD band in Day 0 culture, then a weak PPO band at Day 2 and three PPO bands with one higher activity band at Day 4, whereas three out of four POD bands showed higher activity in this study. The activities of PPO and POD declined when culture continued $(\mathrm{Xu} \& \mathrm{Li}, 2006)$. Our previous study also demonstrated that cutting could activate PAL and promote polyphenol biosynthesis. PPO is involved in the oxidation of polyphenols (Xu et al., 2005; Xu \& Li, 2006).

In summary, it can be concluded that PPO is responsible for the browning of Phalaenopsis leaf explants under the routine culture condition. The induction of $P P O$ gene expression and PPO protein synthesis are mainly seen in the vascular tissues and epidermis where the initial synthesis might take place. The increase of PPO level and activity ultimately promotes the tissue browning. To further understand the molecular mechanism of PPO-mediated enzymatic browning of Phalaenopsis leaf explants, the focus of future work will be placed on exploring PPO location in tissue and cell.

\section{Acknowledgements}

This work was supported by Natural Science Foundation of China (31070618) to C.J. Xu and Natural Science Foundation of Guangdong Province (05300272) to L. Li. 


\section{References}

Chen, G., Chen, D. Y., Wang, T., Xu, C. J., \& Li, L. (2012). Analysis of the proteins related to browning in leaf culture of Phalaenopsis. Scientia Horticulturae, 141, 17-22. http://dx.doi.org/10.1016/j.scienta.2012.03.027

Constabel, C. P., Yip, L., Patton, J. J., \& Christopher, M. E. (2000). Polyphenol Oxidase from Hybrid Poplar. Cloning and Expression in Response to Wounding and Herbivory. Plant Physiology, 124(1), 285-296. http://dx.doi.org/10.1104/pp.124.1.285

Franck, C., Lammertyn, J., Ho, Q. T., Verboven, P., Verlinden, B., \& Nicolaï, B. M. (2007). Browning disorders in pear fruit. Postharvest Biology and Technology, 43(1), 1-13. http://dx.doi.org/10.1016/j.postharvbio.2006.08.008

Holderbaum, D. F., Kon, T., Kudo, T., \& Guerra, M. P. (2010). Enzymatic Browning, Polyphenol Oxidase Activity, and Polyphenols in Four Apple Cultivars: Dynamics during Fruit Development. Hort Science, 45(8), $1150-1154$.

Jiang, Y. M. (2000). Role of anthocyanins, polyphenol oxidase and phenols in lychee pericarp browning. Journal of the Science of Food and Agriculture, 80(3), 305-310. http://dx.doi.org/10.1002/1097-0010(200002)80:3<305::AID-JSFA518>3.0.CO;2-H

Martini, A. N., Papafotiou, M., \& Vemmos, S. N. (2013). Season and Explant Origin Affect Phenolic Content, Browning of Explants, and Micropropagation of $\times$ Malosorbus florentina (Zucc.) Browicz. Hort Science, 48(1), 102-107.

Mayer, A. M., \& Eitan, H. (1979). Polyphenol oxidases in plants. Phytochemistry, 18(2), 193-215. http://dx.doi.org/10.1016/0031-9422(79)80057-6

Mayer, A. M. (2006). Polyphenol oxidases in plants and fungi: going places? A review. Phytochemistry, 67(21), 2318-2331. http://dx.doi.org/10.1016/j.phytochem.2006.08.006

Murata, M., Nishimura, M., Murai, N., Haruta, M., Homma, S., \& Itoh, Y. (2001). A Transgenic Apple Callus Showing Reduced Polyphenol Oxidase Activity and Lower Browning Potential. Bioscience, Biotechnology, and Biochemistry, 65(2), 383-388. http://dx.doi.org/10.1271/bbb.65.383

Murata, M., Tsurutani, M., Hagiwara, S., \& Homma, S.. (1997). subcellur location of plyphenol oxidase in apple. Bioscience, Biotechnology, and Biochemistry, 61(9), 1495-1499. http://dx.doi.org/10.1271/bbb.61.1495

Saltveit, M. E. (2000). Wound induced changes in phenolic metabolism and tissue browning are altered by heat $\begin{array}{lllll}\text { shock. Postharvest Biology and } & \text { Technology, }\end{array}$ http://dx.doi.org/10.1016/S0925-5214(00)00165-4

Sommer, A., Ne'eman, E., Steffens, J. C., Mayer, A. M., \& Harel, E. (1994). Import, Targeting, and Processing of a Plant Polyphenol Oxidase. Plant Physiology, 105(4), 1301-1311. http://dx.doi.org/10.1104/pp.105.4.1301

Stewart, R. J., Sawyer, B. J. B., Bucheli, C. S., \& Robinson, S. P. (2001). Polyphenol oxidase is induced by chilling and wounding in pineapple. Australian Journal of Plant Physiology, 28(3), 181-191. http://dx.doi.org/10.1071/PP00094

Thipyapong, P., \& Steffens, J. C. (1997). Tomato Polyphenol Oxidase (Differential Response of the Polyphenol Oxidase F Promoter to Injuries and Wound Signals). Plant Physiology, 115(2), 409-418. http://dx.doi.org/10.1104/pp.115.2.409

Underhill, S. J. R., \& critchley, C. (1995). Cellular Localisation of Polyphenol Oxidase and Peroxidase Activity in Litchi chinensis Sonn. Pericarp. Australian Journal of Plant Physiology, 22(4), 627-632. http://dx.doi.org/10.1071/PP9950627

Vigyázóa, Lilly Vámos, \& Haardb, N. F. (1981). Polyphenol oxidases and peroxidases in fruits and vegetables. CRC Critical Reviews in Food Science and Nutrition, 15(1), 49-127. http://dx.doi.org/10.1080/10408398109527312

Xu, C. J., Li, L., Li, H., \& Zhang, M. G. (2005). Preliminary studies on the elements of browning and the changes in cellular texture of leaf explant browning in Phalaenopsis. Acta Horticulturae Sinica, 32, 1111-1113.

Xu, C. J., \& Li, L. (2006). Changes of total phenol content and the activities of PPO, POD and PAL during the browning in Phalaenopsis explant in vitro. Acta Horticulturae Sinica, 33(3), 671-674.

Xu, C.J., Li, H., \& Li, L. (2007). Phenylalanine ammonialyase (PAL) gene expression correlated with Phalaenopsis sp. leaf explant browning. Journal of Tropical and Subtropical Boyany, 15(1), 50-54. 
Xu, C. J., Zhou, W. L., Chen, D. Y., Lai, Y. Y., \& Li, L. (2009). Molecular cloning and analysis of homological gene PPO from Phalaenopsis. Acta Horticulturae Sinica, 36(12), 1799-1804.

Yoruk, R., \& Marshall, M. (2003). Physicochemical properties and function of plant polyphenol oxidase: A review. Journal of Food Biochemistry, 27(5), 361-422. http://dx.doi.org/10.1111/j.1745-4514.2003.tb00289.x

Zhao, L. L., Ge, H., Fan, C. H., Yin, F., Li, Q. X., \& Zhou, Y. J.. (2006). Effects of pH and temperature on browning of Phalaenopsis explants cultured in vitro. Acta Horticulturae Sinica, 33, 1373-1376.

Zhao, Y., Yang, S. H. Ge, W. Y., Li, Q. X., Chen, H. X., \& Ge, H. (2010). The metabolism of phenolics and reactive oxygen species in relation to the explant browning differences among the varieties of Phalaenopsis during the tissue culture. Acta Horticulturae Sinica, 37, 963-970.

\section{Copyrights}

Copyright for this article is retained by the author(s), with first publication rights granted to the journal.

This is an open-access article distributed under the terms and conditions of the Creative Commons Attribution license (http://creativecommons.org/licenses/by/3.0/). 